\title{
ARTICLE
}

\section{Optimization of the production of xylanases in corncob-based media by Aspergillus niger and Trichoderma Iongibrachiatum using Taguchi approach}

\author{
Joseph Adetunji Elegbede, Agbaje Lateef ${ }^{\star}$ \\ Laboratory of Industrial Microbiology and Nanobiotechnology, Department of Pure and Applied Biology, Ladoke \\ Akintola University of Technology, PMB 4000, Ogbomoso, Nigeria
}

\begin{abstract}
Xylanases are important in producing several commercially valued bioproducts. In this study, xylanases were produced by Aspergillus niger L3 and Trichoderma longibrachiatum L2 using corncob, an agricultural waste, as sole carbon source. The impact of important fermentation parameters at individual and interactive levels were studied using Taguchi L9 orthogonal array. Substantial variation in enzyme synthesis was observed among designated factor levels. The optimal conditions to produce xylanases were $20 \%$ inoculum size, $24 \mathrm{~h}$ fermentation time, substrate concentration of $15 \mathrm{~g} / \mathrm{l}$ at $\mathrm{pH}$ 5.5 for $A$. niger L3; and inoculum size $12.5 \%, 72 \mathrm{~h}$ fermentation time, substrate concentration of $15 \mathrm{~g} / \mathrm{l}$ at $\mathrm{pH} 5.5$ for $T$. longibrachiatum L2. Validation of outcomes of the optimal combination of parameters resulted in a significant improvement of approximately 208.09 and $192.59 \%$ in the yield of xylanase by A. niger L3 (28.69 to $88.39 \mathrm{U} / \mathrm{ml})$ and $T$. longibrachiatum L2 (22.13 to $64.75 \mathrm{U} / \mathrm{ml})$, respectively. The study therefore established the optimal valorization of corncob to produce xylanase by the fungal isolates.

Acta Biol Szeged 63(1):51-58 (2019)
\end{abstract}

\section{KEY WORDS}

agrowastes

corncob valorization

optimization

Taguchi orthogonal array xylanase

\author{
ARTICLE INFORMATION \\ Submitted \\ 09 February 2019 \\ Accepted \\ 04 May 2019. \\ *Corresponding author \\ E-mail: agbaje72@yahoo.com \\ alateef@lautech.edu.ng
}

\section{Introduction}

Hemicellulose is part of the core constituents of lignocellulose and it is the next most abundant carbohydrate resource on Earth after cellulose (Radhika et al. 2011). Xylan represents the main component of hemicelluloses (Bajaj and Manhas 2012) and is the major backbone in the hemicellulosic portion of the plant cell wall, connecting compounds like arabinose, mannose, glucose and other sugars via an acetyl chain (Radhika et al. 2011). Xylan is a heterogeneous or diverse polysaccharide and contains a linear backbone of $\beta-1,4-D$-xylopyranoside residues and, also short side-chain branches. Xylan can only be completely hydrolyzed using several enzymes due to its composite structure (Bajaj and Manhas 2012). Thus, biodegradation of xylan, requires series of xylanolytic enzymes among which endo- $\beta$-1,4-xylanases (EC 3.2.1.8) hydrolyse the xylan backbones into short xylooligosaccharides (Pandey et al. 2014).

Extracellular xylanases synthesized by microorganisms have incredible industrial significance, with about $20 \%$ of global enzyme market being shared by cellulase, pectinase, and xylanase (Polizeli et al. 2005). The global market of industrial enzymes is said to have witnessed rapid growth in recent years. It was reported to be only 1 million US dollars in 1970 and has grown to 4.5 billion dollars in 2012, with projection to reach about 7.1 billion dollars in 2018 (Kalim et al. 2015).

Microbial enzymes, like xylanases are imperative in numerous fields from food processing to paper and pulp industries (Azin et al. 2007). It contributes a critical role in numerous biotechnological processes such as clarification of fruit juice, bleaching, beer and wine, improving poultry feed digestibility, pulp and paper, leather and baking industries (Uday et al. 2016a). They are utilized in extraction of extracellular polymeric substances (EPS) and plant oils and, also used to enhance the nutritional quality of silage, coffee, green feed and starch (Lakshmi et al. 2009). Moreover, an important usefulness of xylanase has been established to produce biofuel from lignocelluloses (Uday et al. 2016b). Its use most recently reported for the green synthesis of nanoparticles with profound biomedical applications (Elegbede et al. 2018a, 2018b, 2019) has further expanded the frontiers of enzyme technology in nanobiotechnology (Lateef and Adeeyo 2015; Lateef et al. 2015; Adelere and Lateef 2016). Broad types of fungi and bacteria are known to synthesize xylanases under various cultivation systems, but filamentous fungi are the most effective producers of xylanase, because they 
secrete elevated levels of enzymes compared to yeasts and bacteria (Rani et al. 2014). On an industrial scale, xylanases are principally synthesized by Aspergillus and Trichoderma spp. (Shahi et al. 2011). Also, Aspergilli have capability to synthesize broad range of enzymes responsible for degrading plant cell wall. Trichoderma spp., which are foremost agents causing decay and decomposition of agricultural wastes possess an array of different enzymes, and hence they are known as excellent producers of lignocellulolytic enzymes (Azin et al. 2007).

Pure substrates are highly expensive and are not affordable for bulk production of enzymes at industrial level. Therefore, it is essential to survey cheap substrates for cost-effective production of enzymes. Agricultural residues, including animal wastes present a cheap source of raw materials for the industrial production of enzymes (Geetha and Gunasekaran 2010; Lateef et al. 2008, 2010, 2012; Lateef and Gueguim-Kana 2012; Ganaie et al. 2014; Lateef et al. 2015), and they are available in great quantity in countries with wide-ranging agricultural practices (Bajaj and Manhas 2012).

Optimization of production of xylanase is a prerequisite for its large-scale economical production (Azin et al. 2007), and this can be achieved by manipulating important parameters that affect the fermentation process (Rani et al. 2014). Production of xylanase differs in diverse strains and this can be regulated by the nutritional, physiological, and biochemical nature of microbes that are employed (Lakshmi et al. 2009). In this case, it becomes imperative to optimize all fermentation parameters since no definite medium has been authenticated for the maximum production of any metabolite, because the genetic diversity in various microbial sources causes each microorganism or strain to have its unique conditions for the best yield of production (Rao et al. 2008a). Notable fermentation and environmental factors that can manipulate metabolism-mediated yields include temperature, aeration, $\mathrm{pH}$, agitation, carbon and nitrogen sources, incubation time, initial inoculum size, ion requirement amongst others (Prakasham et al. 2007a). Hence, for industrial and commercial production, optimization of growth medium is one of the critical steps to reduce the quantity of unutilized constituents for a cost-effective yield (Lakshmi et al. 2009).

The conventional optimization procedures, including one-factor-at-a-time design entail experimental work which is time consuming and does not provide necessary information about the common interactions of the parameters (Mandal et al. 2015). On the contrary, statistical optimization techniques help to investigate the influence of controlled factor in a multivariate system. Furthermore, bioprocesses have been optimized using response surface methodology (RSM), artificial neural networks (ANN), and genetic algorithm (Gueguim-Kana et al. 2007, 2012a,b;
Adeoye et al. 2015; Adeeyo et al. 2016).

Taguchi orthogonal array (OA) design of experiment (DOE) encompasses the investigation of a system by a set of independent variables (factors or parameters) over specific levels of interest (Taguchi 1986). The technique also determines the relationship or correlation between variables and operational conditions (Mandal et al. 2015). Recent literature reviews reveal that Taguchi methodology has been used to optimize reaction variables in several biochemical processes by studying a given set of independent variables, which may be controllable or uncontrollable over a definite region of interest. It is also imperative that experiments conducted in small scale are valid over an entire experimental region (Uday et al. 2016a). The use of ANOVA (analysis of variance) is to investigate the accuracy of experimental data and gives the statistical relationship of the output (Mandal et al. 2015). Taguchi methodology has been efficiently applied in bioprocesses (Rao et al. 2008b), to optimize the synthesis of some industrial enzymes such as tannase (Mohapatra et al. 2009), alkaline protease (Laxman et al. 2005), $\alpha$-amylase (Uysal et al. 2010) and L-asparaginase (Prakasham et al. 2007b). It is better and superior over other analogous statistical designs, including the RSM, because much less time is needed to execute the experiment. Also, Taguchi method is advantageous to achieve consistency and reliability at little cost with fewer experiments, when compared with RSM and ANN. Its application normally leads to improved quality or yield of products and process performance (Rao et al. 2008b). The improved performance is ensured by the orthogonal layout, whereby interactive effects of different factors are studied with fewer numbers of experimental runs (Rao et al. 2008b). However, Taguchi DOE does not take into accounts of the influence of all the controlling factors in a process, but chiefly concerned about the main effects of the important factors. Also, its application requires a critical brainstorming on the discovery of key parameters, and competence in statistical analysis. It is also expedient that for reliability, the noise factors in the experiment must be properly identified (Rao et al. 2008b).

Most recently, we reported xylanase activities of some fungal isolates, including Aspergillus niger, A. flavus, Trichoderma longibrachiatum, A. fumigatus, Fusarium solani, and Botryodiplodia sp. in our laboratory with potent dough rising and juice clarification activities (Elegbede and Lateef 2018). In the present study, Taguchi method was applied to optimize process parameters to synthesize xylanase by two of the isolates; namely A. niger L3 and T. longibrachiatum L2 in corncob-based media with the aim of improving the enzyme yield for biotechnological applications. The experiments were designed using 4 factors at 3 levels with OA layout of L9 $\left(3^{4}\right)$. 


\section{Materials and Methods}

\section{Microorganisms and maintenance}

Isolates of $A$. niger L 3 and T. longibrachiatum L 2 which were previously isolated in our laboratory (Elegbede and Lateef 2018) were used in this study. They were sub-cultured on fresh sterile potato dextrose agar (PDA) plates, incubated at room temperature $\left(30 \pm 2{ }^{\circ} \mathrm{C}\right)$ for $72 \mathrm{~h}$ and stored on PDA at $4{ }^{\circ} \mathrm{C}$.

\section{Substrate}

Corncobs were locally sourced from Ajegunle market, Oyo, Oyo state, Nigeria, and processed through grinding (0.5 $\mathrm{mm}$ mesh) to obtain fine powder. The percentage moisture content of the corncob powder was estimated by drying the powder to a constant weight at $110{ }^{\circ} \mathrm{C}$ in a hot air oven (Lateef and Gueguim-Kana 2012).

\section{Inoculum preparation}

Inoculum was developed according to the methods of Lateef and Gueguim-Kana (2012) through the transfer of a loopful mycelium of the fungal strain from the plate into a sterilized $50 \mathrm{ml}$ inoculum medium in a $250 \mathrm{ml}$ capacity flask (containing $1 \%$ sucrose, $0.2 \%$ yeast extract, final $\mathrm{pH}$ 5.5). The flask was incubated at $30 \pm 2{ }^{\circ} \mathrm{C}$ on a shaker at $100 \mathrm{rpm}$ for $24 \mathrm{~h}$.

\section{Submerged fermentation}

The basal medium composition for enzyme production was corncob (20.0 g/L), $\mathrm{MgSO}_{4}(2.0 \mathrm{~g} / \mathrm{L}), \mathrm{NaNO}_{3}(1.4$ $\mathrm{g} / \mathrm{L}), \mathrm{KH}_{2} \mathrm{PO}_{4}(1.8 \mathrm{~g} / \mathrm{L}), \mathrm{NH}_{4} \mathrm{Cl}(2.0 \mathrm{~g} / \mathrm{L})$, and $\mathrm{CaCO}_{3}(1.2$ $\mathrm{g} / \mathrm{L}$ ) at starting $\mathrm{pH}$ of 5.7 as previously reported (Elegbede and Lateef 2018). Then, $40 \mathrm{ml}$ of basal medium was dispensed in $250 \mathrm{ml}$ flask, sterilized at $121^{\circ} \mathrm{C}$ for $15 \mathrm{~min}$ and inoculated with $10 \%(\mathrm{v} / \mathrm{v}) 24 \mathrm{~h}$ old inoculum $\left(5 \times 10^{6}\right.$ spores per $\mathrm{ml}$ ). The culture was incubated at $30 \pm 2{ }^{\circ} \mathrm{C}$ on a shaker at $100 \mathrm{rpm}$ for up to $120 \mathrm{~h}$. After specific period of fermentation, the contents were filtered with the aid of Whatman No.1 filter paper, followed by centrifugation at $4000 \mathrm{rpm}$ at $10^{\circ} \mathrm{C}$ for $25 \mathrm{~min}$. The cell-free supernatant was used as crude enzyme and kept at $4{ }^{\circ} \mathrm{C}$ until further use.

\section{Xylanase assay}

Xylanase activity was determined following the methods of Bailey et al. (1992). Exactly $0.9 \mathrm{ml}$ of $0.5 \%(\mathrm{w} / \mathrm{v})$ of beechwood xylan (Megazyme, Ireland) prepared in 0.1 $\mathrm{M}$ sodium citrate buffer at $\mathrm{pH} 5.4$ was reacted with 0.1 $\mathrm{ml}$ of the crude enzyme, and incubated in a water bath shaker at $50{ }^{\circ} \mathrm{C}$ for $30 \mathrm{~min}$. The reaction was terminated by adding $1 \mathrm{ml}$ of 3,5-dinitrosalicyclic acid reagent (DNS acid) to the reaction mixture followed by heating at 100 ${ }^{\circ} \mathrm{C}$ for $10 \mathrm{~min}$. This was followed by cooling to room tem- perature and subsequent measurement of the absorbance at $540 \mathrm{~nm}$ using Spectrumlab S23A spectrophotometer (Yuchengtech, Beijing City, China). Earlier, xylose standard curve was prepared for the extrapolation of the amount of xylose released through the enzymatic hydrolysis of xylan. A unit (U) of xylanase was defined as the amount of enzyme that liberated $1.0 \mu \mathrm{mol}$ of reducing sugar as xylose equivalent per minute in the reaction mixture as described in the above assay conditions. All enzyme determinations were investigated in duplicates.

\section{Taguchi optimization}

Taguchi method was employed in investigating the relationships that exist among the variables of medium components and to optimize for higher yields of enzyme production. Taguchi design methodology was performed using modified steps as stated in Figure 1, and it was used to set up the critical fermentation factors: inoculum size (\%), fermentation time (h), initial $\mathrm{pH}$, and substrate (corncob) concentration $(\mathrm{g} / \mathrm{L})$. The effective levels were set as low, intermediate and high (Table 1) based on earlier experimental values (Elegbede and Lateef 2018). Conditions such as temperature $\left(30 \pm 2{ }^{\circ} \mathrm{C}\right)$, agitation $(100$ $\mathrm{rpm})$, and media: flask volume ratio (40 $\mathrm{ml} / 250 \mathrm{ml}$ flask) were not changed and fixed as standard conditions for the fermentation.

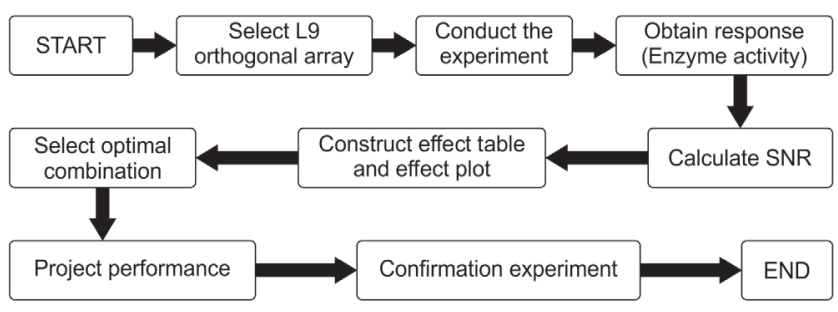

Figure 1. Flowchart for Taguchi optimization method used for xylanase synthesis

Table 1. Culture parameters and their respective levels of variation.

\begin{tabular}{lllll}
\hline \multirow{2}{*}{ Culture parameters } & \multirow{2}{*}{ Units } & \multicolumn{3}{c}{ Levels of variation } \\
& & 1 & 2 & 3 \\
\hline Inoculum size & $\%$ & 5 & 12.5 & 20 \\
Fermentation time & $\mathrm{h}$ & 24 & 72 & 120 \\
Substrate (corncob) & $\mathrm{g} / \mathrm{l}$ & 5 & 15 & 25 \\
Initial pH & & 4 & 5.5 & 7 \\
\hline
\end{tabular}

The appropriate Taguchi design arrangement for data analysis was selected. The L9-orthogonal array method 
Table 2. Experimental set-up (L9 orthogonal array) for xylanase production by A. niger L3 and T. longibrachiatum L2.

\begin{tabular}{|c|c|c|c|c|c|c|c|c|}
\hline \multirow[t]{2}{*}{ Exp. no } & \multirow{2}{*}{$\begin{array}{l}\text { Inoculum } \\
\text { size }\end{array}$} & \multirow{2}{*}{$\begin{array}{l}\text { Fermentation } \\
\text { time }\end{array}$} & \multirow{2}{*}{$\begin{array}{l}\text { Substrate } \\
\text { concentration }\end{array}$} & \multirow{2}{*}{ Initial pH } & $\begin{array}{l}\text { Xylanase activity } \\
\text { (U/ml) }\end{array}$ & $\begin{array}{l}\text { Signal-to-noise } \\
\text { ratio }\end{array}$ & $\begin{array}{l}\text { Xylanase activity } \\
\text { (U/ml) }\end{array}$ & $\begin{array}{l}\text { Signal-to-noise } \\
\text { ratio }\end{array}$ \\
\hline & & & & & \multicolumn{2}{|c|}{ A. niger } & \multicolumn{2}{|c|}{ T. longibrachiatum } \\
\hline 2 & 1 & 2 & 2 & 2 & 53.28 & 34.53128 & 56.83 & 35.09155 \\
\hline 3 & 1 & 3 & 3 & 3 & 12.57 & 21.98671 & 4.51 & 13.08353 \\
\hline 4 & 2 & 1 & 2 & 3 & 39.07 & 31.83687 & 55.87 & 34.94357 \\
\hline 6 & 2 & 3 & 1 & 2 & 41.53 & 32.36724 & 43.45 & 32.75980 \\
\hline 7 & 3 & 1 & 3 & 2 & 62.43 & 35.90787 & 6.15 & 15.77750 \\
\hline 8 & 3 & 2 & 1 & 3 & 31.69 & 30.01844 & 59.16 & 35.44056 \\
\hline 9 & 3 & 3 & 2 & 1 & 43.58 & 32.78574 & 47.68 & 33.56672 \\
\hline
\end{tabular}

based on modified methods described by Taguchi (1986), which overcomes many problems related with conventional methodology, was used for the aforementioned control parameters with three levels of factor variation. In Taguchi method, the summary statistic $\eta$ is called signalto-noise ratio (SNR). The value of $\eta$ is an effective indicator for the assessment of the impact of process parameters on enzyme synthesis. The larger-the-better signal-tonoise was utilized to evaluate the summary statistic $\eta$ in the present study, because an improved production of xylanase was targeted, and it was defined as follows:

$\operatorname{SNR}(\eta)=-10 \log \left(\mathrm{R}^{-2}\right) \quad$ Eqn. 1. (Chou et al. 2003)

Where, SNR represents the signal-to-noise ratio, while $\mathrm{R}$ represents the response or yield of correspondent trials. For each component, the optimal conditions give the largest SNR ratio.

The optimal combination of fermentation parameters was selected using the effect table, and the result was predicted using the formula (Eqn. 2). To validate or confirm the optimized methodology, fermentation experiments were run in duplicates and the samples collected were assayed for xylanase production. ANOVA was performed to evaluate the fermentation parameters that were statistically significant.

$\mathrm{y}_{\mathrm{pr}}=\mathrm{y}_{\mathrm{av}}+\sum_{\mathrm{i}=1}^{\mathrm{n}=4}\left(\mathrm{y}_{\mathrm{opt}}(\mathrm{n})-\mathrm{y}_{\mathrm{ave}}\right)$

Eqn. 2

\section{Results and Discussion}

\section{Unoptimized xylanase production}

Xylanase was produced by A. niger L 3 and T. longibrachiatum L2 strains on corncob supplemented minimal salt media since the use of pure xylan for industrial production of xylanases is uneconomical because of its high cost. Hence, use of cost-effective xylan-rich substrates is highly recommended (Lakshmi et al. 2009). The two fungi utilized corncob effectively as potential source of carbon to produce xylanase (Elegbede and Lateef 2018). Carbon source has been well-known as a noteworthy factor during the growth and metabolic process of any

Table 3. Effect table of xylanase production by A. niger $\mathrm{L} 3$ and T. longibrachiatum L2.

\begin{tabular}{|c|c|c|c|c|}
\hline \multirow{2}{*}{ Levels of parameters } & \multicolumn{4}{|c|}{ Parameters } \\
\hline & Inoculum size & Fermentation time & Substrate concentration & Initial pH \\
\hline \multicolumn{5}{|l|}{ A. niger L3 } \\
\hline 1 & 27.27774 & 31.01998 & 29.23363 & 20.54093 \\
\hline 2 & 22.57531 & 22.69052 & 33.05130 & 34.26880 \\
\hline 3 & 32.90402 & 29.04656 & 20.47213 & 27.94734 \\
\hline \multicolumn{5}{|l|}{ T. longibrachiatum L2 } \\
\hline 1 & 24.18018 & 25.02884 & 30.85527 & 25.04232 \\
\hline 2 & 28.29938 & 29.24230 & 34.53395 & 27.87628 \\
\hline 3 & 28.26160 & 26.47002 & 15.35193 & 27.82256 \\
\hline
\end{tabular}


Table 4. Performance of selected optimal combination of parameters.

\begin{tabular}{lll}
\hline \multirow{2}{*}{ Parameters } & \multicolumn{2}{c}{ Levels } \\
\cline { 2 - 3 } & A. niger L3 & T. longibrachiatum L2 \\
\hline Inoculum size (\%) & 20 & 12.5 \\
Fermentation time (h) & 24 & 72 \\
Substrate concentration (g/L) & 15 & 15 \\
Initial pH & 5.5 & 5.5 \\
Optimum profile & A3B1C2D2 & A2B2C2D2 \\
*Signal-to-noise ratio & 38.92731 & 36.220975 \\
*Xylanase activities (U/ml) & 88.39 & 64.75 \\
\hline
\end{tabular}

*Average of two readings. A: inoculum size, B: fermentation time, C: substrate concentration, D: initial pH

microorganism; therefore, the choice of a suitable carbon source has been identified as a key determinant in the production economics of xylanase (Pandya and Gupte 2012).

Xylanase production was performed in $250 \mathrm{ml}$ Erlenmeyer fasks containing $40 \mathrm{ml}$ of fermentation medium as earlier stated. The time course analysis of xylanase activities showed the commencement of production of xylanase at $24 \mathrm{~h}$ of fermentation for both isolates and reached maximum of $28.69 \mathrm{U} / \mathrm{ml}$ at $96 \mathrm{~h}$ for $A$. niger $\mathrm{L} 3$, and $22.13 \mathrm{U} / \mathrm{ml}$ at $72 \mathrm{~h}$ for $T$. longibrachiatum $\mathrm{L} 2$ as previously reported (Elegbede and Lateef 2018). These productivities were achieved at $\mathrm{pH}$ values of 6.7 and 6.6 for A. niger and T. longibrachiatum L2, respectively. Maximum yields of fungal xylanases have been achieved at $\mathrm{pH}$ of 4.0-6.5 in similar studies (Murthy and Naidu 2012; Yegin 2017).

\section{Optimization of xylanase production through Taguchi method}

Enhancement of production of metabolites by microbes is influenced by the nutritional, physiological, and biochemical nature of the microbe utilized, and these influential factors vary from microorganism to microorganism (Lakshmi et al. 2009). The Taguchi L9 orthogonal array revealed noteworthy variation in xylanase synthesis (Table 2). Initial maximum xylanase production values were observed to be 62.43 and $59.16 \mathrm{U} / \mathrm{ml}$ for $A$. niger $\mathrm{L} 3$ and $T$. longibrachiatum L2, respectively. These results are regarded as the local optimal for xylanase production by both fungal strains. The data presented a very significant improvement in xylanase yields compared to the conventional unoptimized production; 117.60 and $167.33 \%$ for $A$. niger L3 and T. longibrachiatum L2, respectively. Similar variation of enzyme activity was reported by Lakshmi et al (2009). This data further showed that xylanase production by fungal strains is determined by fermentation parameters and their levels.
The Taguchi DOE used for optimization in this study provided the predicted profile for maximum yield of $\mathrm{xy}$ lanase from the effect tables. The $\mathrm{S} / \mathrm{N}$ ratio was used to determine the influence of each variable on the output, and the effect table (Table 3) was employed for the analysis of the relative effect of different parameters. This is because the change in signal leads to a larger effect on the output variable being evaluated. The $\mathrm{S} / \mathrm{N}$ ratio values help in the assessment of the combination of factors that have the maximum influence on the response characteristic of concern, such that higher values of $\mathrm{S} / \mathrm{N}$ ratio indicate greater influence of the combined parameters (Rani et al. 2012). The profiles A3B1C2D2 (interpreted as inoculum; $20 \%$, fermentation time; $24 \mathrm{~h}$, substrate concentration; 15 $\mathrm{g} / \mathrm{L}$, and $\mathrm{pH} ; 5.5$ ) and $\mathrm{A} 2 \mathrm{~B} 2 \mathrm{C} 2 \mathrm{D} 2$ (interpreted as inoculum; $12.5 \%$, fermentation time; $72 \mathrm{~h}$, substrate concentration; $15 \mathrm{~g} / \mathrm{L}$, and $\mathrm{pH}$; 5.5) were generated for $A$. niger L3 and T. longibrachiatum L2, respectively, being the optimum conditions for achieving higher xylanase yields (Table 4).

The optimal combination of parameters was evaluated and the verification experiments, in which optimized conditions were used yielded highest activities of 88.39 and $64.75 \mathrm{U} / \mathrm{ml}$ for A. niger $\mathrm{L} 3$ and T. longibrachiatum $\mathrm{L} 2$, respectively as the global maximum (Table 4). These global maxima obtained from the optimum combination profiles represented 41.58 and $9.45 \%$ increase on the local maxima obtained from the initial orthogonal array experiments. The results indicated a total significant increment of 208.09 and $192.59 \%$ when compared with the conventional unoptimized xylanase synthesis by both A. niger L3 and T. longibrachiatum L2, respectively. These results compared well with previous reports of xylanase production that were optimized using Taguchi method where $277 \%, 161.5 \%, 41.9$ and $10.24 \%$ higher enzyme yields were obtained (Lakshmi et al. 2009; Rani et al. 2014; Mandal et al. 2015). The increase can be claimed to have resulted from the interactions and relations among the various factors (Mandal et al. 2015).

\section{Analysis of Variance (ANOVA)}

Understanding of the influence or effect of each individual factor is crucial for the implementation of a successful bioprocess operation (Rani et al. 2014). Therefore, ANOVA was employed in evaluating results of the orthogonal array experiment and to study the level of consequence of the fermentation parameters on the deviation of the responses (Lakshmi et al. 2009). ANOVA (Table 5) showed that the initial $\mathrm{pH}$, substrate concentration, inoculum size and fermentation time contributed 35.10, 30.93, 19.88 and $14.09 \%$, respectively, to the optimal yield of xylanase by $A$. niger L3, while substrate concentration, inoculum size, fermentation time and initial $\mathrm{pH}$ contributed 88.99, $4.81,3.94$ and $2.26 \%$, respectively, to the optimal yield of 
Table 5. Analysis of variance of main effects of fermentation factors on xylanase production by A. niger L3 and T. longibrachiatum L2.

\begin{tabular}{|c|c|c|c|c|c|c|c|}
\hline & Inoculum size & Fermentation time & Substrate concentration & Initial pH & Error & Pooled error & Total \\
\hline \multicolumn{8}{|l|}{ A. niger L3 } \\
\hline DF & 2 & 2 & 2 & 2 & 0 & 0 & 8 \\
\hline SS & 213.9334 & 151.5649 & 332.7652 & 377.6934 & & & 1075.957 \\
\hline Variance & 106.9667 & 75.78247 & 166.3826 & 188.8467 & & & \\
\hline Percentage contribution & 19.88308 & 14.08652 & 30.92737 & 35.10302 & & & 100 \\
\hline \multicolumn{8}{|l|}{ T. longibrachiatum L2 } \\
\hline DF & 2 & 2 & 2 & 2 & 0 & 0 & 8 \\
\hline SS & 44.83626 & 36.68758 & 829.1145 & 21.01863 & & & 931.657 \\
\hline Variance & 22.41813 & 18.34379 & 414.5572 & 10.50932 & & & \\
\hline Percentage contribution & 4.812529 & 3.937885 & 88.99354 & 2.256048 & & & 100 \\
\hline
\end{tabular}

*DF: degree of freedom, SS: sum of squares

xylanase in the case of T. longibrachiatum L2. While initial $\mathrm{pH}$ has the highest effect on yield of xylanase by A. niger L3, it has the least effect and a very minute significance on T. longibrachiatum L2. This further shows that factors that influence the production of metabolites vary from microorganism to microorganism which can be adduced to genetic diversity, physiology and metabolic differences. The inference of this finding is that more interest should be focused on initial $\mathrm{pH}$ and substrate concentration for A. niger L3, and mainly substrate concentration for $T$. longibrachiatum L2, if the production of xylanases by either of these fungal isolates is to be modulated significantly. Such carbon source or substrate concentration dependent enzyme production has been reported in diverse xylanase synthesizing microbial strains (Oliveira et al. 2006; Kapoor et al. 2008). Also, Rani et al (2014) reported that carbon source (rice straw) produced the greatest effect in the production of xylanase.

\section{Conclusion}

Xylanase production by A. niger L3 and T. longibrachiatum L2 on corncob based media was successfully enhanced through optimization of the fermentation conditions with Taguchi method. Four factors (Inoculum concentration (\%), substrate concentration ( $\mathrm{g} / \mathrm{l})$, fermentation time and initial $\mathrm{pH}$ ) at three levels of variation were used and the analysis confirmed the participation and, also the interactions of the factors. It was ascertained that the optimal conditions for production of xylanases by $A$. niger L3 and T. longibrachiatum L2 were inoculum; 20\%, fermentation time; $24 \mathrm{~h}$, substrate concentration; $15 \mathrm{~g} / \mathrm{l}$, and $\mathrm{pH} ; 5.5$ and inoculum; $12.5 \%$, fermentation time; 72 h, substrate concentration; $15 \mathrm{~g} / \mathrm{l}$, and $\mathrm{pH} ; 5.5$, respectively. Using the optimum conditions, enzyme yield was significantly improved to about 208.09 and $192.59 \%$ for A. niger L3 and T. longibrachiatum L2, respectively. Also, it was established that more attention should be focused on initial $\mathrm{pH}$ and substrate concentration for A. niger L3, and mainly substrate concentration for $T$. longibrachiatum L2, if the production of xylanases by any of the fungal isolates is to be significantly adjusted or altered. It can therefore be concluded that corncob can be valorized to produce xylanase by the fungal isolates.

\section{Acknowledgement}

Authors thank Dr. T.B. Asafa of Department of Mechanical Engineering, LAUTECH, Ogbomoso, Nigeria for the assistance on Taguchi optimization technique.

\section{References}

Adeeyo AO, Lateef A, Gueguim-Kana EB (2016) Optimization of the production of extracellular polysaccharide from the Shiitake medicinal mushroom Lentinus edodes (Agaricomycetes) using mutation and a genetic algorithm-coupled artificial neural network (GA-ANN). Int J Med Mushrooms 18:571-581.

Adelere IA, Lateef A (2016) A novel approach to the green synthesis of metallic nanoparticles: the use of agro-wastes, enzymes and pigments. Nanotechnol Rev 5:567-587.

Adeoye AO, Lateef A, Gueguim-Kana EB (2015) Optimization of citric acid production using a mutant strain of Aspergillus niger on cassava peel substrate. Biocatal Agric Biotechnol 4:568-574.

Azin M, Moravej R, Zareh D (2007) Production of xylanase by Trichoderma longibrachiatum on a mixture of wheat bran and wheat straw: Optimization of culture condition by 
Taguchi method. Enzyme Microb Technol 40:801-805.

Bailey MJ, Biely P, Poutanen K (1992) Interlaboratory testing for methods of assay of xylanase activity. J Biotechnol 23:257-270.

Bajaj BK, Manhas K (2012) Production and characterization of xylanase from Bacillus licheniformis P11(C) with potential for fruit juice and bakery industry. Biocatal Agric Biotechnol 1:330-337.

Chou WJ, Sun CH, Yu GP, Huang JH (2003) Optimization of the deposition process of $\mathrm{ZrN}$ and $\mathrm{TiN}$ thin films on $\operatorname{Si}\left(\begin{array}{lll}1 & 0 & 0\end{array}\right)$ using design of experiment method. Mater Chem Phys 82:228-236.

Elegbede JA, Lateef A (2018) Valorization of corn-cob by fungal isolates for production of xylanase in submerged and solid-state fermentation media and potential biotechnological applications. Waste Biomass Valor 9:1273-1287.

Elegbede JA, Lateef A, Azeez MA, Asafa TB, Yekeen TA, Oladipo IC, Adebayo EA, Beukes LS, Gueguim-Kana EB (2018a) Fungal xylanases-mediated synthesis of silver nanoparticles for catalytic and biomedical applications. IET Nanobiotechnol 12:857-863.

Elegbede JA, Lateef A, Azeez MA, Asafa TB, Yekeen TA, Oladipo IC, Aina DA, Beukes LS, Gueguim-Kana EB (2018b) Biofabrication of gold nanoparticles using xylanases through valorization of corncob by Aspergillus niger and Trichoderma longibrachiatum: antimicrobial, antioxidant, anticoagulant and thrombolytic activities. Waste Biomass Valor. (https://doi.org/10.1007/s12649018-0540-2).

Elegbede JA, Lateef A, Azeez MA, Asafa TB, Yekeen TA, Oladipo IC, Abbas SH, Beukes LS, Gueguim-Kana EB (2019) Silver-gold alloy nanoparticles biofabricated by fungal xylanases exhibited potent biomedical and catalytic activities. Biotechnol Prog. 2019 May 3:e2829. doi:10.1002/btpr.2829.

Ganaie MA, Lateef A, Gupta US (2014) Enzymatic trends of fructooligosaccharides production by microorganisms. Appl Biochem Biotechnol 172:2143-2159.

Geetha K, Gunasekaran P (2010) Optimisation of nutrient medium containing agricultural wastes for xylanase production by Bacillus pumilus B20. Biotechnol Bioprocess Eng 15:882-889.

Gueguim-Kana EB, Oloke JK, Lateef A, Adesiyan MO (2012a) Modeling and optimization of biogas production on saw dust and other co-substrates using Artificial Neural Network and Genetic Algorithm. Renew Energy 46:276-281.

Gueguim-Kana EB, Oloke JK, Lateef A, Oyebanji A (2012b) Comparative evaluation of artificial neural network coupled genetic algorithm and response surface methodology for modelling and optimization of citric acid production by Aspergillus niger MCBN 297. Chem Eng Trans 27:397-402.
Gueguim-Kana EB, Oloke JK, Lateef A, Zebaze Kana MG (2007) Novel optimal temperature profile for acidification process of Lactobacillus bulgaricus and Streptococcus thermophilus in yoghurt fermentation using artificial neural network and genetic algorithm. J Ind Microbiol Biotechnol 34:491-496.

Kalim B, Böhringer N, Ali N, Schäberle TF (2015) Xylanase from microbial origin to industrial application. Br Biotechnol J 7:1-20.

Kapoor M, Nair LM, Kuhad RC (2008) Cost-effective xylanase production from free and immobilized Bacillus pumilus strain MK001 and its application in saccharification of Prosopis juliflora. Biochem Eng J 38:88-97.

Lakshmi GS, Rao CS, Rao RS, Hobbs PJ, Prakasham RS (2009) Enhanced production of xylanase by a newly isolated Aspergillus terreus under solid state fermentation using palm industrial waste: A statistical optimization. Biochem Eng J 48:51-57.

Lateef A, Adeeyo AO (2015) Green synthesis and antibacterial activities of silver nanoparticles using extracellular laccase of Lentinus edodes. Not Sci Biol 7:405-411.

Lateef A, Adelere IA, Gueguim-Kana EB, Asafa TB, Beukes LS (2015) Green synthesis of silver nanoparticles using keratinase obtained from a strain of Bacillus safensis LAU 13. Int Nano Lett 5:29-35.

Lateef A, Gueguim-Kana EB (2012) Utilization of cassava wastes in the production of fructosyltransferase by Rhizopus stolonifer LAU 07. Rom Biotechnol Lett 17:7309-7316. Lateef A, Oloke JK, Gueguim-Kana EB, Oyeniyi SO, Onifade OR, Oyeleye AO, Oladosu OC, Oyelami AO (2008) Improving the quality of agro-wastes by solid-state fermentation: enhanced antioxidant activities and nutritional qualities. World J Microbiol Biotechnol 24:2369-2374.

Lateef A, Oloke JK, Gueguim-Kana EB, Sobowale BO, Ajao SO, Bello BY (2010) Keratinolytic activities of a new feather-degrading isolate of Bacillus cereus LAU 08 isolated from Nigerian soil. Int Bioremed Biodegrad 64:162-165.

Lateef A, Oloke JK, Gueguim-Kana EB, Raimi OR (2012) Production of fructosyltransferase by a local isolate of Aspergillus niger in both submerged and solid substrate media. Acta Aliment 41:100-117.

Lateef A, Adelere IA, Gueguim-Kana EB (2015) Bacillus safensis LAU 13: a new source of keratinase and its multi-functional biocatalytic applications. Biotechnol Equip 29:54-63.

Laxman RS, Sonawane AP, More SV, Rao BS, Rele MV, Jogdand VV, Deshpande VV, Rao MB (2005) Optimization and scale up of production of alkaline protease from Conidiobolus coronatus. Process Biochem 40:3152-3158.

Mandal A, Kar S, Dutta T, Pati BR, Mondal KC, Mohapatra PKD (2015) Parametric optimization of submerged fermentation conditions for xylanase production by Bacillus 
cereus BSA1 through Taguchi Methodology. Acta Biol Szeged 59:189-195.

Mohapatra PD, Maity C, Rao RS, Pati BR, Mondal KC (2009) Tannase production by Bacillus licheniformis KBR6: Optimization of submerged culture conditions by Taguchi DOE methodology. Food Res Int 42:430-435.

Murthy PS, Naidu MM (2012) Production and application of xylanase from Penicillium sp. utilizing coffee by-products. Food Bioprocess Technol 5:657-664.

Oliveira LA, Porto AL, Tambourgi EB (2006) Production of xylanase and protease by Penicillium janthinellum CRC $87 \mathrm{M}-115$ from different agricultural wastes. Bioresour Technol 97:862867.

Pandey S, Shahid M, Srivastava M, Sharma A, Singh A, Kumar V, Yatindra S (2014) Isolation and optimized production of xylanase under solid state fermentation condition from Trichoderma sp. Int J Adv Res 2:263-273.

Pandya JJ, Gupte A (2012) Production of xylanase under solid-state fermentation by Aspergillus tubingensis JP-1 and its application. Bioprocess Biosystems Eng 35:769-779.

Polizeli MLTM, Rizzatti ACS, Monti R, Terenzi HF, Jorge JA, Amorim DS (2005) Xylanases from fungi: properties and industrial applications. Appl Microbiol Biotechnol 67:577-591.

Prakasham RS, Subba Rao C, Sreenivas Rao R, Sarma PN (2007a) Enhancement of acid amylase production by an isolated Aspergillus awamori. J Appl Microbiol 102:204211.

Prakasham RS, Rao C, Rao RS, Lakshmi GS, Sarma PN (2007b) L-asparaginase production by isolated Staphylococcus sp. - 6A: design of experiment considering interaction effect for process parameter optimization. J Appl Microbiol 102:1382-1391.

Radhika K, Ravinder R, Ravindra P (2011) Bioconversion of pentose sugars into ethanol: a review and future directions. Biotechnol Mol Biol Rev 6:8-20.

Rani GB, Chiranjeevi T, Chandel AK, Satish T, Radhika K, Narasu ML, Uma A (2014) Optimization of selective production media for enhanced production of xylanases in submerged fermentation by Thielaviopsis basicola MTCC 1467 using L16 orthogonal array. J Food Sci Technol 51:2508-2516.

Rao CS, Sathish T, Mahalaxmi M, Laxmi GS, Rao RS, Prakasham RS (2008a) Modeling and optimization of fermentation factors for enhancement of alkaline protease production by isolated Bacillus circulans using feed-forward neural network and genetic algorithm. J Appl Microbiol 104:889-898.

Rao RS, Kumar CG, Prakasham RS, Hobbs PJ (2008b) The Taguchi methodology as a statistical tool for biotechnological applications: A critical appraisal. Biotechnol J 3:510-523.

Shahi SS, Alemzadeh I, Khanahmadi M, Roostaazad R (2011) Xylanase production under solid state fermentation by Aspergillus niger. Int J Trans B: Applications 24:197.

Taguchi G (1986) Introduction to Quality Engineering: Designing Quality into Products and Processes. Asian Productivity Organization (American Supplier Institute, Dearborn, MI, USA)

Uday USP, Bandyopadhyay TK, Bhunia B (2016a) Rapid development of xylanase assay conditions using Taguchi methodology. Bioengineered 7:424-431.

Uday USP, Choudhury P, Bandyopadhyay TK, Bhunia B (2016b) Classification, mode of action and production strategy of xylanase and its application for biofuel production from water hyacinth. Int J Biol Macromol 82:1041-1054.

Uysal E, Akcan N, Baysal Z, Uyar F (2010) Optimization of $\alpha$-amylase production by Bacillus subtilis RSKK96: using the Taguchi experimental design approach. Prep Biochem Biotechnol 41:84-93.

Yegin S (2017) Xylanase production by Aureobasidium pullulans on globe artichoke stem: Bioprocess optimization, enzyme characterization and application in saccharification of lignocellulosic biomass. Prep Biochem Biotechnol 47:441-449. 